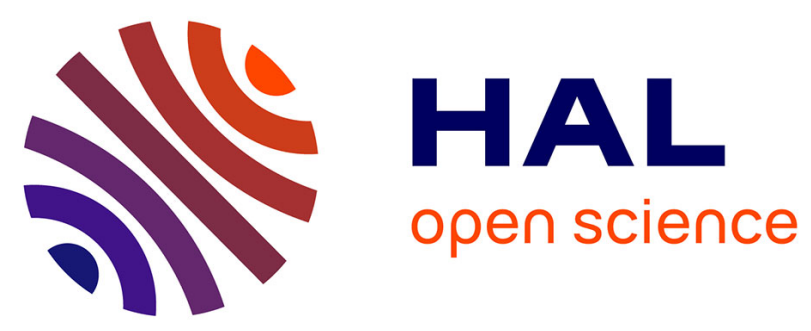

\title{
Comparative environmental impacts of glyphosate and conventional herbicides when used with glyphosate-tolerant and non-tolerant crops.
}

\author{
Laure Mamy, Benoit Gabrielle, Enrique Barriuso
}

\section{- To cite this version:}

Laure Mamy, Benoit Gabrielle, Enrique Barriuso. Comparative environmental impacts of glyphosate and conventional herbicides when used with glyphosate-tolerant and non-tolerant crops.. Environmental Pollution, 2010, 158 (10), pp.3172-3178. 10.1016/j.envpol.2010.06.036 . hal-01192142

\author{
HAL Id: hal-01192142 \\ https://hal.science/hal-01192142
}

Submitted on 31 May 2020

HAL is a multi-disciplinary open access archive for the deposit and dissemination of scientific research documents, whether they are published or not. The documents may come from teaching and research institutions in France or abroad, or from public or private research centers.
L'archive ouverte pluridisciplinaire HAL, est destinée au dépôt et à la diffusion de documents scientifiques de niveau recherche, publiés ou non, émanant des établissements d'enseignement et de recherche français ou étrangers, des laboratoires publics ou privés. 


\title{
Comparative environmental impacts of glyphosate and conventional herbicides when used with glyphosate-tolerant and non-tolerant crops
}

\author{
Laure Mamy*,1, Benoît Gabrielle, Enrique Barriuso \\ INRA-AgroParisTech, UMR 1091 Environnement et Grandes Cultures, 78850 Thiverval-Grignon, France \\ The impacts of herbicide applications on glyphosate-tolerant crops could be higher than expected due to the accumulation of a metabolite of \\ glyphosate in soils.
}

\section{A R T I C L E I N F O}

\section{Article history:}

Received 16 February 2010

Received in revised form

18 June 2010

Accepted 29 June 2010

\section{Keywords:}

Herbicide

Metabolite

Impact

PRZM

USES

\begin{abstract}
A B S T R A C T
The introduction of glyphosate-tolerant (GT) crops is expected to mitigate the environmental contamination by herbicides because glyphosate is less persistent and toxic than the herbicides used on non-GT crops. Here, we compared the environmental balances of herbicide applications for both crop types in three French field trials. The dynamic of herbicides and their metabolites in soil, groundwater and air was simulated with PRZM model and compared to field measurements. The associated impacts were aggregated with toxicity potentials calculated with the fate and exposure model USES for several environmental endpoints. The impacts of GT systems were lower than those of non-GT systems, but the accumulation in soils of one glyphosate metabolite (aminomethylphosphonic acid) questions the sustainability of GT systems. The magnitude of the impacts depends on the rates and frequency of glyphosate application being highest for GT maize monoculture and lowest for combination of GT oilseed rape and non-GT sugarbeet crops.
\end{abstract}

(c) 2010 Elsevier Ltd. All rights reserved.

\section{Introduction}

The introduction of crops tolerant to glyphosate ( $\mathrm{N}$-(phosphonomethyl)glycine), a broad spectrum herbicide, is expected to decrease the environmental contamination by agro-chemicals because it reduces the number of herbicides used, and because glyphosate is less persistent and toxic than the herbicides used on non-tolerant crops (Giesy et al., 2000; Mamy et al., 2005; Shaner, 2000). However, there is a paucity of data to substantiate that claim beyond theoretical principles.

Most of the studies comparing the herbicide applications on glyphosate-tolerant (GT) and non-GT crops focused on the assessment of the exposure of some environmental compartments (soil, water, air, non-target organisms) (Cerdeira and Duke, 2006; Laitinen et al., 2006; Mamy et al., 2008; Wauchope et al., 2002), and only a few of them aimed at assessing and comparing the impacts of herbicides used in both crop types (Bennett et al., 2004; Brimner et al., 2005; Devos et al., 2008; Peterson and Hulting,

\footnotetext{
* Corresponding author.

E-mail addresses: laure.mamy@versailles.inra.fr (L. Mamy), benoit.gabrielle@ agroparistech.fr (B. Gabrielle), barriuso@grignon.inra.fr (E. Barriuso).

1 Present address: INRA, UR 251 PESSAC, Route de Saint Cyr, 78026 Versailles, France.
}

2004). The exposure is the result of the emission of herbicides due to the agricultural practices and depends on the characteristics of environment, soil and climate, while the impact combined the emission of herbicides with their toxicity (Bockstaller et al., 2008). Using various approaches ranging from simple indicators, which transform variables into scores then sum up or aggregate in an empirical way (Bockstaller et al., 2009), to life cycle assessment, these scant studies show that the impacts of glyphosate as used on GT crops are generally lower than those of the herbicides involved in weed control in non-GT crops. However, these results involved two major limitations. First, the data on pesticides inputs and fate were not obtained under the same agronomic and pedo-climatic conditions for GT and non-GT crops. Secondly, the metabolites of herbicides, which are sometimes more persistent in the environment than active substances (Mamy et al., 2005) and which can play an important role in risks and impacts assessment (Kolpin et al., 2004; Van Zelm et al., 2010) were not considered.

The objective of this work was thus to compare the environmental impacts of glyphosate, as used on GT oilseed rape, GT sugarbeet and GT maize, with that of other herbicides frequently used for weed control on the same crops, albeit non-GT. The herbicides included trifluralin (2,6-dinitro- $N, N$-dipropyl-4-trifluoromethylaniline) and metazachlor (2-chloro- $N$-(2,6-dimethyl-phenyl)- $N$ (pyrazol-1-ylmethyl)acetamide) for oilseed rape (Brassica napus L.), 
metamitron (4-amino-4,5-dihydro-3-methyl-6-phenyl-1,2,4-triazin5-one) for sugarbeet (Beta vulgaris L.), and sulcotrione (2-(2-chloro4-mesylbenzoyl)cyclohexane-1,3-dione) for maize (Zea mays L.).

It should be noted that the weed control in non-GT crops usually involves more active ingredients than those mentioned above (Mamy et al., 2005). In the case of oilseed rape, those make up a relatively marginal fraction of the total herbicide applications. On the other hand, metamitron is usually supplemented with two herbicides on sugarbeet, with combined application rates similar to that of metamitron. As for maize, there are very few data on sulcotrione, but its use is recommended in France as an alternative to atrazine, now banned in Europe. In addition, we assumed that the other pesticide treatments (fungicide, insecticide, molluscicide, and plant growth regulator) were similar for all crops. The comparison is therefore unbalanced in favour of the weed control based on selective herbicides. This may be justified by the fact that we wanted to test the generally-admitted hypothesis that GT-based cropping systems have lower environmental impacts than non-GT based cropping systems. If verified under such stringent conditions, the hypothesis would hold true for more comprehensive comparisons.

The assessment of the impacts of the different cropping systems was done according to the following four general steps of life cycle assessment (USEPA, 2006): (1) goal definition and scoping (in this study, comparison of the impacts of herbicide applications); (2) qualitative and quantitative inventory analysis (emissions of herbicides, that is their concentrations in soil, water and air); (3) impact assessment (for example, impact of the concentration in soil on water potability); (4) interpretation (comparison of the total impacts of the two systems). The quantitative inventory of herbicides emissions (step 2) was done by simulating the amounts of herbicides and metabolites in soil, water and air for 20 years with the numerical model PRZM (Pesticide Root Zone Model, Carsel et al., 1998). The model was parameterized with laboratory data obtained in the same conditions (soil, temperature, moisture, dose) for the five herbicides (Mamy and Barriuso, 2005; Mamy et al., 2005). PRZM was chosen because it is widely used and has been shown to provide reliable results for these herbicides in France (Mamy et al., 2008). This model uses a balanced and consistent approach to the range of processes determining the fate of pesticides in the environment, including sorption, degradation, volatilisation, leaching, plant uptake, runoff, erosion, and plant wash-off (Carsel et al., 1998). It is also one of the models used in environmental risk assessment for pesticide registration in many countries (Europe, USA). The impacts were then assessed (step 3 ) with toxicity potentials (or characterization factors) which allow determination of the relative importance of the substance to toxicity related impact categories (endpoints) such as human toxicity (Huijbregts et al., 2005). Several methods to determine the toxicity potentials (TP) of pesticides have been published (for example Antón et al., 2004; Huijbregts et al., 2000; Humbert et al., 2007; Juraske et al., 2009a; Margni et al., 2002; Rosenbaum et al., 2008; Van Zelm et al., 2009). Among them, the method of Huijbregts et al. (2000) using the USES (Uniform System for the Evaluation of Substances) model (RIVM et al., 1998) was selected because, contrary to others, it allows calculation of TP for the metabolites of pesticides, for several emission and target compartments, and is adapted for the Western Europe. Toxicity potentials will allow aggregation of emissions of herbicides and metabolites to estimate the final impacts of various cropping systems on human being, water, sediment and terrestrial ecosystems (step 4).

\section{Materials and methods}

\subsection{Field sites and cropping systems}

Three experimental sites representative of the main production regions for oilseed rape, sugarbeet and maize in France were selected, in which field trials involving GT crops had been carried out since 1995. The sites were located near Châlons-en-Champagne (thereafter denoted Châlons, Northeastern France), Dijon (Central) and Toulouse (SouthWest).

The Châlons soil is a superficial Rendzina developed over limestone subsoil, the Dijon soil is a calcareous Cambisol with clay-loam texture, and the Toulouse soil is a desaturated Cambisol with silt-loam texture (Mamy et al., 2005).

The trials comprised rotations with GT sugarbeet, winter wheat and GT oilseed rape, and GT maize monoculture. The resulting crops successions are listed in Table 1, along with the herbicides applications. The yields of GT and non-GT crops were identical.

\subsection{Modelling the fate of herbicides in the long term with PRZM}

The fate of the five herbicides in the long term was simulated with PRZM 3.12 (Carsel et al., 1998). The model was parameterized with laboratory data (Table 2; Mamy and Barriuso, 2005; Mamy et al., 2005), and tested against field data collected in one of the sites (Dijon) (Mamy et al., 2008). PRZM provided satisfactory predictions of dissipation and vertical distribution in soil profile of the substances applied on the site (glyphosate, trifluralin, metazachlor) and of AMPA. In general, data from laboratory allowed an acceptable parameterization of the model as indicated by goodness of fit indices (Mamy et al., 2008). Further details concerning the model and its parameterization can be found in Mamy (2004) and Mamy et al. (2008).

To assess the risks of environmental contamination by herbicides, several scenarios of crops succession and management based on actual field trials were built: an oilseed rape - wheat - sugarbeet rotation and a maize monoculture with gradual introduction of GT crops, resulting in an annual frequency of GT crops varying from 0 to $100 \%$ (Table 1 ).

To model the fate of the foliar herbicides glyphosate and sulcotrione, we assumed that $20 \%$ of the applied rate was intercepted by crops and weeds, and ran two simulations (Mamy et al., 2008). The first one involved the fraction of applied herbicide that directly reached the soil surface (i.e., $80 \%$ of the total dose), and was based on the degradation rate measured in the laboratory in soils (Mamy et al., 2005). The second simulation involved the remaining $20 \%$ of the total dose, which was intercepted by plants. We used the degradation rate measured by incubating plant residues containing glyphosate or sulcotrione in soils (Mamy, 2004) (Table 2). All other input data were identical for the two simulations.

The model was run on series of 20 years historical weather data in all sites, spanning the 1970-1990 period. An extra 2-year (without herbicide applications) was simulated at the beginning of each run to reach an equilibrium, and was discarded in the analysis. The fluxes of volatilization to air and leaching below the root zone (set at the $0.6 \mathrm{~m}$ depth for Châlons and Toulouse and $0.9 \mathrm{~m}$ depth for Dijon) cumulated over the 20 years period, and the final soil concentrations of each molecule (on the 31 st December of the year following the last herbicide application)

Table 1

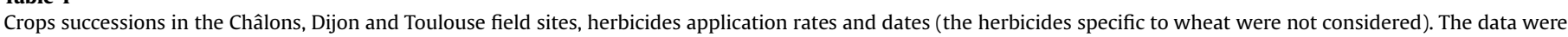
obtained from CETIOM, ITB and Arvalis.

\begin{tabular}{|c|c|c|c|}
\hline Crops succession & $\begin{array}{l}\text { Annual frequency } \\
\text { of GT crops (\%) }\end{array}$ & $\begin{array}{l}\text { Herbicides application rates } \\
\left(\mathrm{kg} \mathrm{ha}^{-1} \text { application }^{-1}\right)\end{array}$ & Herbicides application dates \\
\hline Maize monoculture & 0 & Sulcotrione $(0.45)$ & 20th May \\
\hline Wheat - Sugarbeet - & 0 & Metamitron (2.8) & 20th April \\
\hline Wheat - Oilseed rape & & Trifluralin (1.2) + Metazachlor (0.75) & 4 th September +15 th September \\
\hline Wheat - Sugarbeet - & 25 & Metamitron (2.8) & 20th April \\
\hline Wheat - GT oilseed rape & & Glyphosate (1.44) & 17th October \\
\hline Wheat - GT sugarbeet - & 25 & Glyphosate (3.06) & 15th May \\
\hline Wheat - Oilseed rape & & Trifluralin (1.2) + Metazachlor (0.75) & 4 th September +15 th September \\
\hline Wheat - GT sugarbeet - & 50 & Glyphosate (3.06) & 15th May \\
\hline Wheat - GT oilseed rape & & Glyphosate (1.44) & 17th October \\
\hline GT maize monoculture & 100 & Glyphosate (2.88) & 15th June \\
\hline
\end{tabular}


Table 2

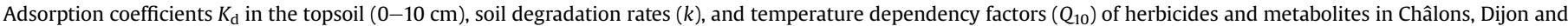

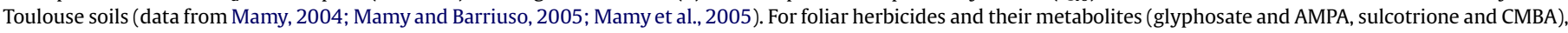
the degradation rates in soil after absorption by crop ( $\left.k_{\text {crop }}\right)$ are also presented.

\begin{tabular}{|c|c|c|c|c|c|c|c|c|c|c|c|c|}
\hline & \multicolumn{4}{|l|}{ Châlons } & \multicolumn{4}{|l|}{ Dijon } & \multicolumn{4}{|l|}{ Toulouse } \\
\hline & $\overline{K_{\mathrm{d}}\left(\mathrm{L} \mathrm{kg}^{-1}\right)}$ & $k\left(\mathrm{~d}^{-1}\right)$ & $k_{\text {crop }}\left(\mathrm{d}^{-1}\right)$ & $Q_{10}$ & $K_{\mathrm{d}}\left(\mathrm{L} \mathrm{kg}^{-1}\right)$ & $k\left(\mathrm{~d}^{-1}\right)$ & $k_{\text {crop }}\left(\mathrm{d}^{-1}\right)$ & $Q_{10}$ & $K_{\mathrm{d}}\left(\mathrm{L} \mathrm{kg}^{-1}\right)$ & $k\left(\mathrm{~d}^{-1}\right)$ & $k_{\text {crop }}\left(\mathrm{d}^{-1}\right)$ & $Q_{10}$ \\
\hline Glyphosate & 29.0 & 0.260 & 0.077 & 2.1 & 42.8 & 0.142 & 0.042 & 2.3 & 68.5 & 0.094 & 0.028 & 2.1 \\
\hline$A M P A^{\mathrm{a}}$ & 33.2 & 0.026 & 0.008 & - & 32.0 & 0.020 & 0.006 & - & 37.1 & 0.009 & 0.003 & - \\
\hline Trifluralin & 53.1 & 0.021 & - & 1.4 & 46.8 & 0.018 & - & 2.1 & 36.2 & 0.037 & - & 1.8 \\
\hline Metazachlor & 1.4 & 0.290 & - & 1.7 & 1.06 & 0.0216 & - & 1.7 & 0.8 & 0.174 & - & 1.9 \\
\hline$M 4^{\mathrm{b}}$ & 0.8 & 0.003 & - & - & 0.5 & 0.002 & - & - & 0.4 & 0.002 & - & - \\
\hline Metamitron & 1.5 & 0.066 & - & 0.9 & 1.3 & 0.239 & - & 1.5 & 1.1 & 0.018 & - & 1.7 \\
\hline Sulcotrione & 0.5 & 0.228 & 0.126 & 1.2 & 0.5 & 0.178 & 0.098 & 1.3 & 0.6 & 0.203 & 0.112 & 2.1 \\
\hline$C M B A^{\mathrm{c}}$ & 0.9 & 0.009 & 0.005 & - & 1.1 & 0.014 & 0.008 & - & 1.1 & 0.012 & 0.007 & - \\
\hline
\end{tabular}

a AMPA: aminomethylphosphonic acid, metabolite of glyphosate.

b M4: unidentified metabolite of metazachlor.

c CMBA: 2-chloro-4-methylsulfonylbenzoic acid, metabolite of sulcotrione.

were taken as input into the toxicity model USES. Both rotations ending with sugarbeet or oilseed rape were simulated. Since no significant differences were observed between them (data not shown), only the results of rotation ending with oilseed rape are presented.

\subsection{Determination of herbicides and metabolites toxicity potentials} with the USES model

The multi-media fate and exposure model USES 2.0 has been developed for quantitative assessment of the risks posed by substances to man and the environment (RIVM et al., 1998). It was used to compute the toxicity potentials (TP) associated with the herbicides and their metabolites (Huijbregts et al., 2000).

The model considers six endpoints: five global environmental endpoints (freshwater, seawater, freshwater sediments, marine sediments, and terrestrial ecosystems), and one particular population (human being). Human exposure is calculated via the food and water ingestion, and respiratory intake pathways, while for global targets it is expressed as the mean concentrations calculated in the corresponding compartments.

The resulting risks are quantified by a risk characterization ratio $(R C R)$ value:

\section{$R C R=P D I / A D I$, for human being}

$R C R=P E C / P N E C$, for global targets

where PDI, ADI, PEC and PNEC are the predicted daily intake, acceptable daily intake, predicted environmental concentration and predicted no effect concentration, respectively.

For any given substance, $R C R$ s are calculated for several compartments of initial emission (air, sea and freshwater, agricultural and industrial soils) and for each final target (freshwater, seawater, freshwater sediments, marine sediments, terrestrial ecosystems, and human being). Each compartment of initial emission can have an impact on each target. RCRs are ultimately normalised by the RCRs of a reference substance, 1,4-dichlorobenzene (1,4-DCB), which yields the TP (1,4-DCB is the equivalent of $\mathrm{CO}_{2}$ in the calculation of global warming impacts).

Of the five herbicides we tested, only sulcotrione was not listed in the USES 2.0 database. We thus calculated toxicity potentials with the USES 2.0 model based on our laboratory data (Table 2) and on the Agritox database (Agritox, 2010). In addition, the main metabolites of glyphosate (aminomethylphosphonic acid, AMPA), sulcotrione (2-chloro-4-methylsulfonylbenzoic acid, CMBA) and metazachlor (unidentified, M4) (Mamy et al., 2005) were considered. The TPs of AMPA were calculated: the sorption and degradation parameters were taken from the laboratory data (Table 2), the physico-chemical data and the PNEC, were taken from the literature (Grunewald et al., 2001; Traas and Smit, 2003); and the ADI was considered equal to that of glyphosate (Agritox, 2010; WHO, 2005). The ADI were $0.410^{-3}$ and $0.3 \mathrm{mg} \mathrm{kg}^{-1} \mathrm{~d}^{-1}$, and the PNEC 5.1 and $79.7 \mu \mathrm{g} \mathrm{L}^{-1}$ for sulcotrione and AMPA, respectively. In the absence of specific physico-chemical and toxicity data, the TPS of CMBA and M4 were considered the same as their parent molecule as the toxicity of metabolites is generally similar or lower than that of the parent (Sinclair and Boxall, 2003).

Table 3 lists the TPs calculated with USES for the herbicides and one of the metabolites involved in our study (AMPA). The results presented thereafter were focused on the three most relevant compartments of initial emission (agricultural soils, freshwater, air) for pesticides in agricultural use, and three endpoints: human being, freshwater, and terrestrial ecosystems, since the results for the aquatic and sediments compartments were highly correlated (Huijbregts et al., 2005).

\subsection{Impact scores of herbicide applications}

The impact score $I$ of the emission into compartment $c$ of $m \mathrm{~kg}$ of substance $s$ on a particular target $t$ is then calculated as:
$I=m \times T P_{c, t, s}$

where $I$ is expressed in $\mathrm{kg}$ eq. $1,4-\mathrm{DCB}$ (the reference substance), $T P_{c, t, s}$ is the toxicity potential for target $t$ associated with the emission of substance $s$ in environmental compartment $c$, and $m$ is the concentration of the substance in soil, water and air calculated with PRZM. Thus, the higher the score, the higher the impact. However, as this method allows a relative assessment of the impacts there are no threshold values for TP and $I$. The final impact score $I_{\mathrm{f}}$ of the total herbicides applications in one cropping system was calculated by summing the impact scores of the used herbicides and of their relevant metabolites:

$I_{\mathrm{f}}=\sum I_{\text {Herbicides }}+\sum I_{\text {Metabolites }}$

\section{Results and discussion}

\subsection{Modelling the fate of herbicides in the long term}

Fig. 1 summarises the simulated fluxes and stocks of the herbicides and their metabolites after 20 years, in the three field sites with the various crops successions.

Since only trifluralin was predicted to volatilize, the corresponding results are not presented on Fig. 1. The fraction of

\section{Table 3}

Toxicity potentials of the five herbicides and one of their metabolites (AMPA) for three compartments of initial emission (agricultural soils, freshwater, air) and three targets (human being, freshwater, terrestrial ecosystems). The toxicity potentials are expressed in $\mathrm{kg}$ eq. $1,4-\mathrm{DCB} \mathrm{\textrm {kg } ^ { - 1 }}$ substance, and were taken from Huijbregts et al. (2000), except where indicated.

\begin{tabular}{|c|c|c|c|c|}
\hline \multirow{2}{*}{$\begin{array}{l}\text { Herbicide/ } \\
\text { Metabolite }\end{array}$} & \multirow[t]{2}{*}{ Target } & \multicolumn{3}{|c|}{ Initial emission compartment } \\
\hline & & $\begin{array}{l}\text { Agricultural } \\
\text { soils }\end{array}$ & Freshwater & Air \\
\hline Glyphosate & $\begin{array}{l}\text { Human being } \\
\text { Freshwater } \\
\text { Terrestrial ecosystems }\end{array}$ & $\begin{array}{l}1.510^{-2} \\
9.210^{-1} \\
9.610^{-2}\end{array}$ & $\begin{array}{l}6.610^{-2} \\
1.410^{3} \\
2.210^{-11}\end{array}$ & $\begin{array}{ll}3.1 & 10^{-3} \\
2.2 & 10^{1} \\
4.7 & 10^{-2}\end{array}$ \\
\hline$A M P A^{\mathrm{a}}$ & $\begin{array}{l}\text { Human being } \\
\text { Freshwater } \\
\text { Terrestrial ecosystems }\end{array}$ & $\begin{array}{l}0.4 \\
1.0 \\
2.410^{-2}\end{array}$ & $\begin{array}{l}0.3 \\
1.210^{2} \\
0.0\end{array}$ & $\begin{array}{l}0.6 \\
3.3 \\
1.110^{-2}\end{array}$ \\
\hline Trifluralin & $\begin{array}{l}\text { Human being } \\
\text { Freshwater } \\
\text { Terrestrial ecosystems }\end{array}$ & $\begin{array}{ll}1.2 & 10^{2} \\
4.0 & 10^{1} \\
3.5 & 10^{1}\end{array}$ & $\begin{array}{ll}9.7 & 10^{1} \\
2.7 & 10^{4} \\
1.3 & 10^{-2}\end{array}$ & $\begin{array}{l}1.7 \\
9.9 \\
1.710^{-2}\end{array}$ \\
\hline Metazachlor & $\begin{array}{l}\text { Human being } \\
\text { Freshwater } \\
\text { Terrestrial ecosystems }\end{array}$ & $\begin{array}{l}4.910^{1} \\
3.9 \\
1.710^{-1}\end{array}$ & $\begin{array}{l}1.7 \\
1.510^{2} \\
1.410^{-6}\end{array}$ & $\begin{array}{l}6.8 \\
7.4 \\
7.410^{-2}\end{array}$ \\
\hline Metamitron & $\begin{array}{l}\text { Human being } \\
\text { Freshwater } \\
\text { Terrestrial ecosystems }\end{array}$ & $\begin{array}{l}6.5 \\
4.110^{-1} \\
4.210^{-2}\end{array}$ & $\begin{array}{l}1.610^{-1} \\
2.310^{1} \\
8.510^{-10}\end{array}$ & $\begin{array}{l}8.810^{-1} \\
9.310^{-1} \\
1.910^{-2}\end{array}$ \\
\hline Sulcotrione $^{a}$ & $\begin{array}{l}\text { Human being } \\
\text { Freshwater } \\
\text { Terrestrial ecosystems }\end{array}$ & $\begin{array}{l}6.410^{2} \\
2.2 \\
7.5\end{array}$ & $\begin{array}{l}1.410^{1} \\
1.210^{2} \\
2.410^{-10}\end{array}$ & $\begin{array}{l}8.710^{1} \\
4.8 \\
3.4\end{array}$ \\
\hline
\end{tabular}

a Calculated (see Materials and methods). 

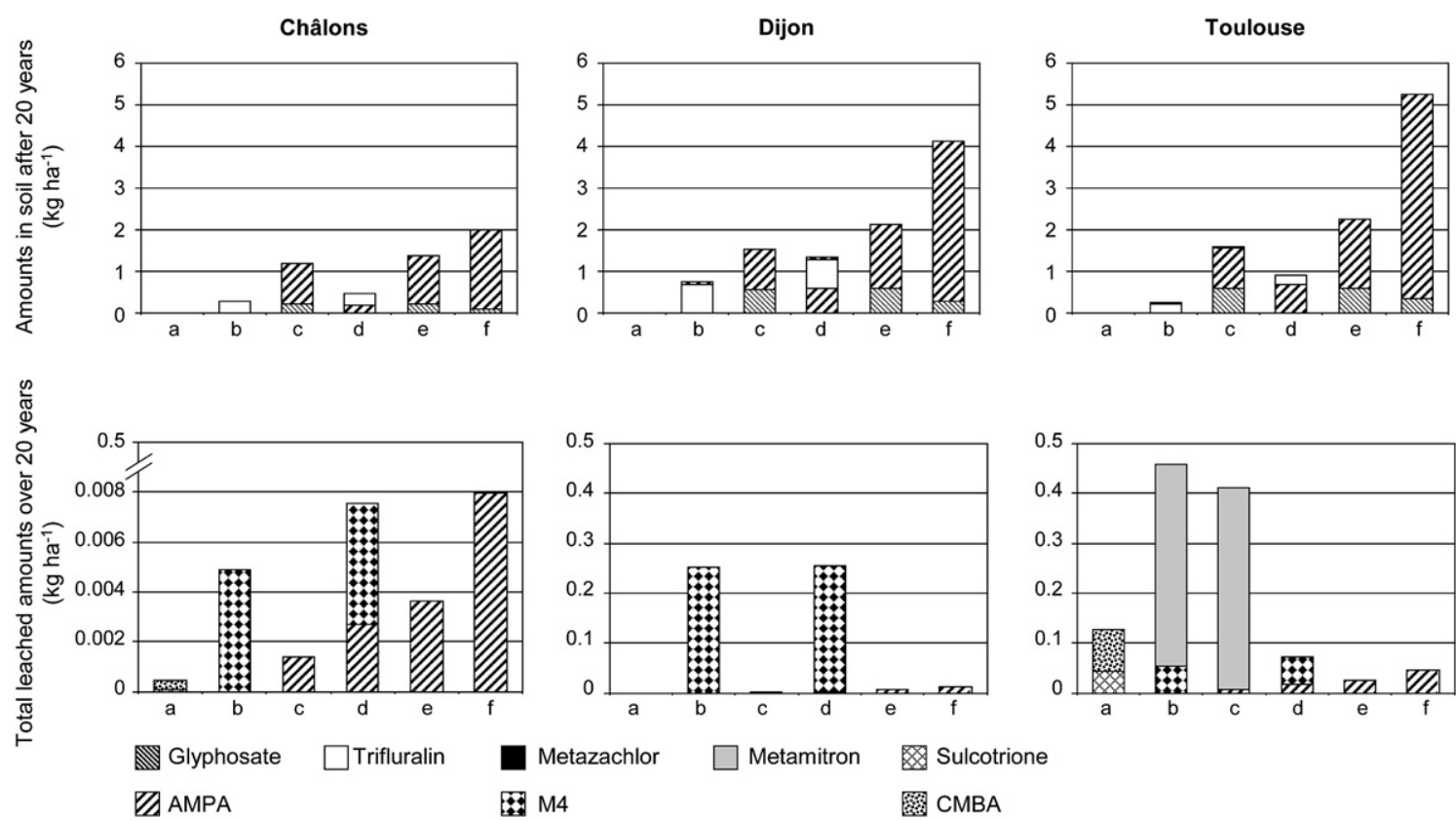

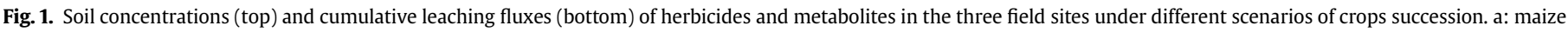

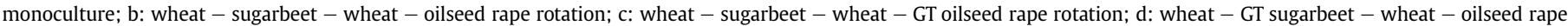
rotation; e: wheat - GT sugarbeet - wheat - GT oilseed rape rotation; f: GT maize monoculture.

volatilized trifluralin ranged from $10.3 \%$ to $16.8 \%$ of the annual application rate, which is in the range of measurements reported values at the field scale (Bedos et al., 2006).

Only a few herbicides or metabolites persisted in soil more than few weeks after application: glyphosate, AMPA and trifluralin in all soils, M4 in the Dijon soil, and metamitron in the Toulouse soil. AMPA was the most persistent substance, and the build-up increased as the frequency of occurrence of GT crops increased in the crops succession (Fig. 1). Modelling showed maximum amount of AMPA in soil of $4.9 \mathrm{~kg} \mathrm{ha}^{-1}$ on the 31 st December after 20 years of annual glyphosate application in maize monoculture, making up $8.5 \%$ of the total amount of glyphosate applied over the 20 years period (this concentration having reached a plateau after 10 years). The simulated residual amounts ranged from 0.001 to $8.2 \%$ of the total applied for glyphosate, from 3.5 to $11.3 \%$ for trifluralin, from 0.1 to $1.8 \%$ of the applied metazachlor recovered as unidentified metabolite M4 (assuming for M4 the same molecular weight as metazachlor), and was $0.18 \%$ for metamitron in Toulouse soil. For the other molecules, the residues were lower than $0.2 \%$ of the total applied. These results are consistent with observations (Table 4; Mamy et al., 2008), and with several field studies (Baer and Calvet, 1999; Berger et al., 1999;

\section{Table 4}

Observed residual amounts ( $\mu \mathrm{g} \mathrm{kg} \mathrm{kg}^{-1}$ soil) of glyphosate, AMPA, trifluralin, and metamitron in Châlons, Dijon and Toulouse soils in 2000 after five years cropping of GT oilseed rape - wheat - GT sugarbeet rotation or GT maize monoculture (source: CETIOM, ITB and Arvalis).

\begin{tabular}{|c|c|c|c|c|c|c|}
\hline \multirow[b]{2}{*}{ Soil depth } & \multicolumn{2}{|l|}{$\begin{array}{l}\text { Châlons } \\
\text { (Rotation) }\end{array}$} & \multicolumn{2}{|c|}{$\begin{array}{l}\text { Dijon } \\
\text { (Rotation) }\end{array}$} & \multicolumn{2}{|c|}{$\begin{array}{l}\text { Toulouse } \\
\text { (Monoculture) }\end{array}$} \\
\hline & $0-30 \mathrm{~cm}$ & $30-60 \mathrm{~cm}$ & $0-30 \mathrm{~cm}$ & $30-60 \mathrm{~cm}$ & $0-30 \mathrm{~cm}$ & $30-60 \mathrm{~cm}$ \\
\hline \multicolumn{7}{|l|}{ Molecule } \\
\hline Glyphosate & $10-25$ & $10-25$ & $10-25$ & $<10$ & $<50$ & $<50$ \\
\hline AMPA & $10-25$ & $10-25$ & $<10$ & $<10$ & 71 & 55 \\
\hline Trifluralin & $<10$ & $<10$ & $10-25$ & $10-25$ & $-{ }^{a}$ & - \\
\hline Metamitron & $<50$ & $<50$ & $<50$ & $<50$ & - & - \\
\hline
\end{tabular}

a Not applicable.
Capri et al., 1995; Gomides Freitas et al., 2008; Laitinen et al., 2006; Rouchaud et al., 1992; Vischetti et al., 1997).

The persistence of all molecules was strongly dependent on soil type (Fig. 1) because of the variability of their degradation and retention properties across soils (Table 2 ), which was sometimes as large as the variability across molecules for a given soil type (Mamy and Barriuso, 2005; Mamy et al., 2005). This confirms that herbicides should be compared under similar or even strictly identical soil conditions.

PRZM predicted no leaching of glyphosate under the root zone, whatever the cropping systems. This is in accordance with the high $K_{\mathrm{d}}$ values of this molecule (Table 2), our observations (Table 4; Mamy et al., 2008), and other experimental results (Borggaard and Gimsing, 2008; Vereecken, 2005). On the contrary, PRZM predicted the leaching of AMPA in significant amounts, particularly in the Toulouse soil where this substance was the most persistent (Table 2) (range of average annual concentration for all GT systems in all soils: $0.0017-0.031 \mu \mathrm{g} \mathrm{L}^{-1}$ ). The leaching of AMPA in field conditions was observed by Kjaer et al. (2005) and Veiga et al. (2001). In addition, AMPA was detected below $60 \mathrm{~cm}$ depth in the three soils (Table 4; Mamy et al., 2008). Significant leaching of sulcotrione, CMBA and metamitron in Toulouse soil (average annual concentration of $0.029,0.057$ and $0.199 \mu \mathrm{g} \mathrm{L}^{-1}$ respectively), and M4 in Dijon and Toulouse soil ( 0.011 and $0.009 \mu \mathrm{g} \mathrm{L}^{-1}$ respectively) were also predicted by PRZM (Fig. 1), as could be expected from their low sorption coefficients (Table 2 ) and with the literature (Cherrier et al., 2005; Rouchaud et al., 1998; Vischetti et al., 1997). Conversely, there was no predicted leaching of trifluralin because of its high Kd (Fig. 1; Table 2; Laabs et al., 2000; Malterre et al., 1998).

The amounts of AMPA that may reach groundwater were higher than those of sulcotrione in the three soils, higher than those of CMBA and metamitron in two of the three soils (Châlons and Dijon), but lower than those of M4 in the three soils (Fig. 1). Therefore, the use of GT crops might decrease the risks of groundwater contamination via leaching in some situations. The main differences between the GT and non-GT based cropping systems lied in the possible build-up of AMPA in soils for the former, and in an 
increased contamination of groundwater and air due to CMBA, M4, metamitron and trifluralin for the latter.

\subsection{Impacts of herbicide applications}

From the modelled concentrations of pesticides in the various environmental compartments (air, soils and groundwater) at the field-scale, the method of Huijbregts et al. (2000) allowed us to predict the associated impacts on other environmental endpoints (freshwater and terrestrial ecosystems), and on human being. The impact scores of herbicide applications in the different crops succession systems are summarized on Fig. 2, where the contribution of GT and non-GT crops to the scores is detailed. In general, the impacts were highest in the Toulouse soil, followed by the Dijon and Châlons soils. This is consistent with the highest persistence and/or mobility of the herbicides and metabolites in the Toulouse soil (Table 2; Mamy and Barriuso, 2005; Mamy et al., 2005). The high impacts of the rotations including non-GT oilseed rape and non-GT sugarbeet, and non-GT oilseed rape and GT sugarbeet in Dijon are mainly due to the persistence of trifluralin (Table 2). The differences among the three sites were also due to different climatic conditions that play an important role in the fate of herbicides (Mamy, 2004): Toulouse had the highest average air temperature $\left(12.7^{\circ} \mathrm{C}\right)$, and the highest average annual precipitations occurred in Dijon (774 mm).

The impact scores showed that the systems using glyphosate had lower impacts on human health than those based on selective herbicides (Fig. 2). These results agree with those of Bennett et al. (2004) and Devos et al. (2008) showing that the impact on human of GT sugarbeet and GT maize would be lower than that of non-GT crops. However, our results hinge on the assumption that AMPA had a toxicity identical to glyphosate, due to a lack of specific data. Should AMPA have a 10-times higher toxicity than its parent molecule, as suggested by Sinclair and Boxall (2003) as a general upper-bound, the impacts of GT crops would be higher those of non-GT crops (data not shown). Another uncertainty lies in the prediction by PRZM of the persistence of AMPA in soils. Assuming again the same toxicity for glyphosate and AMPA, a multiplication of AMPA residues in soils by a factor of two to five would bring the impacts of GT maize on human health above those of non-GT maize. This could be expected because of the accumulation of AMPA in the soils (Fig. 1) (it will also depend on the pedo-climatic characteristics and on the application rates).

The impacts of GT-maize monoculture on terrestrial ecosystems were higher than those of non-GT maize because of repeated and frequent applications of glyphosate leading to high residual amounts of glyphosate and AMPA in soils compared to sulcotrione and CMBA (Fig. 1). However, in the other rotations, GT crops had lower impacts on terrestrial ecosystems than non-GT crops, which is consistent with the low ecotoxicity of glyphosate and AMPA (Cerdeira and Duke, 2006; Giesy et al., 2000), and in accordance with the assessment of Devos et al. (2008) and Peterson and Hulting (2004). Nevertheless, the improved weed control in GT crops may affect the abundance of weeds that can have some consequences on the biodiversity of invertebrates, wildlife and birds since weeds provide shelter and a food supply for these animals (Cerdeira and Duke, 2006; Kleter et al., 2008; Turner, 2004). However, this ecological effect is not considered in the USES model. The highest impacts were found for the rotation involving non-GT oilseed rape, and the lowest for the rotation involving GT oilseed rape because of the toxicity of trifluralin (Roberts, 1998). The magnitude of the impacts correlated positively with the persistence of herbicides (Fig. 2; Table 2).

With regard to freshwater, the lowest impacts were found for the combination of GT oilseed rape and non-GT sugarbeet in the Châlons and Dijon soils; but in the Toulouse soil, increased use of GT crops led to a decrease of the impact on freshwater (Fig. 2). This is due to the low mobility of glyphosate and AMPA in this soil compared to selective herbicides (Table 2). Among the selective herbicides, metamitron had the highest impacts on freshwater, followed by M4, then sulcotrione because of the leaching of its metabolite, CMBA (Fig. 2). Low impact of GT crops on groundwater was also reported by Devos et al. (2008) and Peterson and Hulting (2004).

The frequency and rates of glyphosate application directly influenced the magnitude of the impacts, with the following ranking (from highest to lowest): GT maize monoculture $>$ GT sugarbeet $>$ GT oilseed rape. Among the selective herbicides, metamitron had the highest impacts on freshwater followed by sulcotrione because of its metabolite, CMBA. Metazachlor had the lowest impact scores because of its low persistence, while trifluralin had an intermediate profile because of its high volatilization flux and high ecotoxicity. As a result, GT oilseed rape and non-GT sugarbeet appeared as the least polluting combination in the crop rotations, depending to some extent on soil type. Direct comparison of these rotations with the maize monoculture was not possible since the wheat herbicides were not included in this assessment, however some of them are known to be persistent and/or mobile in the soils (Sørensen et al., 2003). This means that only half of the wheat - sugarbeet - wheat - oilseed rape rotation was evaluated compared to the whole rotation for the maize monoculture.
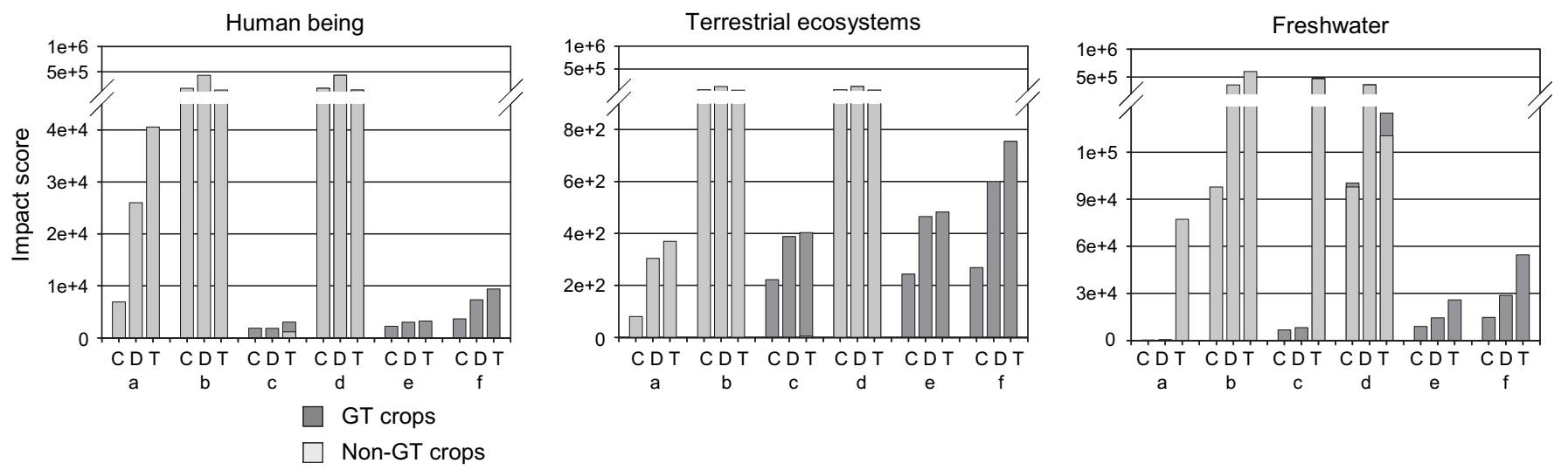

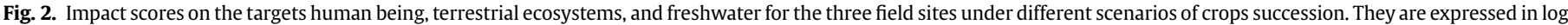

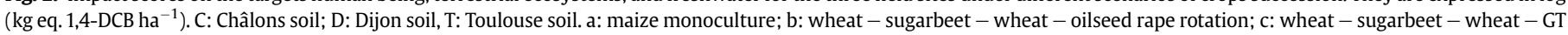
oilseed rape rotation; d: wheat - GT sugarbeet - wheat - oilseed rape rotation; e: wheat - GT sugarbeet - wheat - GT oilseed rape rotation; f: GT maize monoculture. 


\subsection{Performance and limits of the method}

The numerical validation of risk assessment systems is difficult since risks cannot be directly measured; nevertheless the accuracy with which the system predicts exposure levels (i.e., the estimated concentrations in the environment) may be expressed quantitatively (Bockstaller and Girardin, 2003; RIVM et al., 1998). Here, the concentrations of herbicides (and their metabolites) in the environment were estimated with PRZM, which provided a satisfactory prediction of the fate of three herbicides and AMPA in field conditions (Mamy et al., 2008). The consistency between model simulations, field observations and literature data was good (see Section 3.1), and can be considered as a first step in the validation of the overall risk assessment method.

The main limits of this study were: (1) the fact that the simulations with PRZM did not take into account erosion and runoff in the fate of pesticides, although they could play an important role in some situations (Reichenberger et al., 2007); (2) the assumption that M4 and CMBA had the same TP as their parent, for lack of data; (3) the USES model not considering pesticide diffusion to plants as a primary source of emission to the environment, which is important for foliar pesticides sprayed on plants (Juraske et al., 2007, 2009b). Since these limits were identical for all herbicides, it may be assumed that they only had a minor effect on the relative comparison of herbicides' impacts. It should be noted that the USES model, and consequently the impact scores, are sensitive to the values of the toxicity input parameters. Therefore, their parameterization has to be very accurate.

Compared to the other available methods of pesticides risk and impact assessment, ours allows a large coverage of environmental issues, encompassing aquatic and terrestrial risks, human health and the major exposure pathways. The use of a process-oriented pesticide fate model (PRZM) has the advantage of taking local conditions and drivers into account, as illustrated by the differences between soils, thus providing in-depth analysis on the impacts of pesticides. This is expected to avoid incorrect conclusions, because PRZM is a widely-tested model, and better transparency (Kägi et al., 2008). Furthermore, the PRZM-USES system allows an aggregation of the impacts of different pesticides, albeit assuming a lack of interactions between substances. Finally, one of the main advantages of the PRZM-USES method is that it allows consideration of the metabolites of pesticides.

\section{Conclusion}

Here, we carried out an overall assessment allowing a rigorous comparison of the environmental impacts of herbicide applications on GT and non-GT crops, using a similar set of hypotheses and field conditions.

Under the stringent conditions of this assessment (whereby only the main herbicides involved in the weed control of non-GT crops were compared to glyphosate), the substitution of non-GT crops by GT crops could decrease the contamination of groundwater and air, and the impact on human health. The magnitude of the impacts and the relative impacts of the different herbicide applications were highly dependent on the agro-pedo-climatic conditions. However, the potential benefits of GT crops rely mainly on AMPA, and to its accumulation in soils, which will depend on dose, soil, climate, and crop. To our knowledge, this study was the first one taking AMPA into account in the assessment of the impacts of GT crops, showing the importance of considering metabolites in all assessment. Therefore, future research is warranted regarding the fate and toxicity of metabolites, and particularly AMPA, a likely threat to the environment since increasingly detected in water in France (IFEN, 2009).
Nevertheless, this assessment of the impacts of herbicide applications on GT and non-GT crops was based on pure active substances and did not take into account the adjuvants of commercial products which may change the fate and toxicological effects of active substances (Krogh et al., 2003). We assumed only one application of glyphosate per crop, however, several treatments could be done and it is highly probable that other herbicides than glyphosate will be added in GT systems (Devos et al., 2008). In addition, the evolution of weed resistance to glyphosate could also enhance the application rates of glyphosate, particularly in GT-maize monoculture. These might increase the impacts of GT crops compared with those of non-GT crops.

The method we developed in this study, coupling laboratory data - pesticide fate model - toxicity estimation aggregation, which use the physico-chemical properties of pesticides, allowed a fine discrimination and screening of contrasted agro-pedo-climatic conditions. It may be generalized to assess other technical programs in agriculture, for example no tillage with glyphosate use and conventional tillage based on ploughing.

\section{Acknowledgements}

The Authors acknowledge CETIOM, ITB, and Arvalis for providing data of herbicides residues in soils, and the referees for their constructive comments. This work was funded by the programs "Organismes génétiquement modifiés et environnement" of INRA (National Institute for Agricultural Research, France), and "Impact des biotechnologies dans les agro-écosystèmes" of CNRS (Centre National de la Recherche Scientifique). Laure Mamy was supported by a fellowship from INRA and CETIOM.

\section{References}

Agritox, 2010. http://www.dive.afssa.fr/agritox (accessed 11.06.10).

Antón, A., Castells, F., Montero, J.I., Huijbregts, M., 2004. Comparison of toxicological impacts of integrated and chemical pest management in Mediterranean greenhouses. Chemosphere 54, 1225-1235.

Baer, U., Calvet, R., 1999. Fate of soil applied herbicides: experimental data and prediction of dissipation kinetics. Journal of Environmental Quality 28, 1765-1777.

Bedos, C., Rousseau-Djabri, M.F., Gabrielle, B., Flura, D., Durand, B., Barriuso, E., Cellier, P., 2006. Measurement of trifluralin volatilization in the field: relation to soil residue and effect of soil incorporation. Environmental Pollution 144, 958-966.

Bennett, R., Phipps, R., Strange, A., Grey, P., 2004. Environmental and human health impacts of growing genetically modified herbicide-tolerant sugar beet: a lifecycle assessment. Plant Biotechnology Journal 2, 273-278.

Berger, B.M., Dühlmeier, D., Siebert, C.F., 1999. Tillage effects on persistence and distribution of trifluralin in soil. Journal of Environmental Quality 28, 1162-1167.

Bockstaller, C., Girardin, P., 2003. How to validate environmental indicators. Agricultural Systems 76, 639-653.

Bockstaller, C., Guichard, L., Makowski, D., Aveline, A., Girardin, P., Plantureux, S., 2008. Agri-environmental indicators to assess cropping and farming systems. A review. Agronomy for Sustainable Development 28, 139-149.

Bockstaller, C., Guichard, L., Keichinger, O., Girardin, P., Galan, M.-B., Gaillard, G., 2009. Comparison of methods to assess the sustainability of agricultural systems. A review. Agronomy for Sustainable Development 29, 223-235.

Borggaard, O.K., Gimsing, A.L., 2008. Fate of glyphosate in soil and the possibility of leaching to ground and surface waters: a review. Pest Management Science 64, $441-456$.

Brimner, T.A., Gallivan, G.J., Stephenson, G.R., 2005. Influence of herbicide-resistant canola on the environmental impact of weed management. Pest Management Science 61, 47-52.

Capri, E., Ghebbioni, C., Trevisan, M., 1995. Metamitron and chloridazon dissipation in a silty clay loam soil. Journal of Agricultural and Food Chemistry 43, 247-253.

Carsel, R.F., Imhoff, J.C., Hummel, P.R., Cheplick, J.M., Donigian Jr., A.S., 1998. PRZM 3, A Model for Predicting Pesticide and Nitrogen Fate in the Crop Root and Unsaturated Soil Zones: Users Manual for Release 3.12. National Exposure Research Laboratory, Office of Research and Development, US Environment Protection Agency, Athens, GA, USA.

Cerdeira, A.L., Duke, S.O., 2006. The current status and environmental impacts of glyphosate-resistant crops: a review. Journal of Environmental Quality 35, 1633-1658. 
Cherrier, R., Boivin, A., Perrin-Ganier, C., Schiavon, M., 2005. Sulcotrione versus atrazine transport and degradation in soil columns. Pest Management Science 61, 899-904.

Devos, Y., Cougnon, M., Vergucht, S., Bulcke, R., Haesaert, G., Steurbaut, W., Reheul, D., 2008. Environmental impact of herbicide regimes used with genetically modified herbicide-resistant maize. Transgenic Research 17, 1059-1077.

Giesy, J.P., Dobson, S., Solomon, K.R., 2000. Ecotoxicological risk assessment for Roundup ${ }^{\circledR}$ herbicides. Review of Environmental Contamination and Toxicology 167, 35-120.

Gomides Freitas, L., Singer, H., Müller, S.R., Schwarzenbach, R.P., Stamm, C., 2008. Source area effects on herbicide losses to surface waters - A case study in the Swiss Plateau. Agriculture, Ecosystems and Environment 128, 177-184.

Grunewald, K., Schmidt, W., Unger, C., Hanschmann, G., 2001. Behavior of glyphosate and aminomethylphosphonic acid (AMPA) in soils and water of reservoir Radeburg II catchment (Saxony/Germany). Journal of Plant Nutrition and Soil Science $164,65-70$.

Huijbregts, M.A.J., Thissen, U., Guinée, J.B., Jager, T., Kalf, D., van de Meent, D., Ragas, A.M.J., Wegener Sleeswijk, A., Reijnders, L., 2000. Priority assessment of toxic substances in life cycle assessment. Part I: calculation of toxicity potentials for 181 substances with the nested multi-media fate, exposure and effects model USES-LCA. Chemosphere 41, 541-573.

Huijbregts, M.A.J., Struijs, J., Goedkoop, M., Heijungs, R., Hendriks, A.J., van de Meent, D., 2005. Human population intake fractions and environmental fate factors of toxic pollutants in life cycle impact assessment. Chemosphere 61, 1495-1504.

Humbert, S., Margni, M., Charles, R., Torres Salazar, O.M., Quirós, A.L., Jolliet, O., 2007. Toxicity assessment of the main pesticides used in Costa Rica. Agriculture, Ecosystems and Environment 118, 183-190.

IFEN (Institut Français de l'Environnement), 2009. Les pesticides dans les Eaux. Données 2006. http://www.ifen.fr/donnees-essentielles/eau/ (accessed 11.06.10)

Juraske, R., Antón, A., Castells, F., Huijbregts, M.A.J., 2007. Human intake fractions of pesticides via greenhouse tomato consumption: comparing model estimates with measurements for captan. Chemosphere 67, 1102-1107.

Juraske, R., Mutel, C.L., Stoessel, F., Hellweg, S., 2009a. Life cycle human toxicity assessment of pesticides: comparing fruit and vegetables diets in Switzerland and the United States. Chemosphere 77, 939-945.

Juraske, R., Castells, F., Vijay, A., Muñoz, P., Antón, A., 2009b. Uptake and persistence of pesticides in plants: measurements and model estimates for imidacloprid after foliar and soil application. Journal of Hazardous Materials 165, 683-689.

Kägi, T., Bockstaller, C., Gaillard, G., Hayer, F., Mamy, L., Strassemeyer, J., 2008. Multicriteria evaluation of RA and LCA assessment methods considering pesticide application. European Network for the Durable Exploitation of crop protection strategies (ENDURE), Internal Report.

Kjaer, J., Olsen, P., Ullum, M., Grant, R., 2005. Leaching of glyphosate and aminomethylphosphonic acid from Danish agricultural field sites. Journal of Environmental Quality 34, 608-620.

Kleter, G.A., Harris, C., Stephenson, G., Unsworth, J., 2008. Comparison of herbicides regimes and the associated potential environmental effects of glyphosateresistant crops versus what they replace in Europe. Pest Management Science 64, 479-488.

Kolpin, D.W., Schnoebelen, D.J., Thurman, E.M., 2004. Degradates provide insight to spatial and temporal trends of herbicides in ground water. Ground Water 42 , 601-608.

Krogh, K.A., Halling-Sørensen, B., Mogensen, B.B., Vejrup, K.V., 2003. Environmental properties and effects of nonionic surfactant adjuvants in pesticides: a review. Chemosphere 50, 871-901.

Laabs, V., Amelung, W., Pinto, A., Altstaedt, A., Zech, W., 2000. Leaching and degradation of corn and soybean pesticides in an Oxisol of the Brazilian Cerrados. Chemosphere 41, 1441-1449.

Laitinen, P., Siimes, K., Eronen, L., Rämö, S., Welling, L., Oinonen, S., Mattsoff, L., Ruohonen-Lehto, M.R., 2006. Fate of the herbicides glyphosate, glufosinateammonium, phenmedipham, ethofumesate and metamitron in two Finnish arable soils. Pest Management Science 62, 473-491.

Malterre, F., Pierre, J.-G., Schiavon, M., 1998. Trifluralin transfer from top soil. Ecotoxicology and Environmental Safety 39, 98-103.

Mamy, L., 2004. Comparaison des impacts environnementaux des herbicides à large spectre et des herbicides sélectifs: caractérisation de leur devenir dans le sol et modélisation. Ph.D. Thesis, Institut National Agronomique Paris-Grignon. http://www.inra fr/ea/fichier these/MAMY-L.pdf (accessed 11.06.10).

Mamy, L., Barriuso, E., 2005. Glyphosate adsorption in soils compared to herbicides replaced with the introduction of glyphosate resistant crops. Chemosphere 61 , $844-855$
Mamy, L., Barriuso, E., Gabrielle, B., 2005. Environmental fate of herbicides trifluralin, metazachlor, metamitron and sulcotrione compared with that of glyphosate, a substitute broad spectrum herbicide for different glyphosate-resistant crops. Pest Management Science 61, 905-916.

Mamy, L., Gabrielle, B., Barriuso, E., 2008. Measurement and modelling of glyphosate fate compared to that of herbicides replaced as a result of the introduction of glyphosate-resistant oilseed rape. Pest Management Science 64, 262-275.

Margni, M., Rossier, D., Crettaz, P., Jolliet, O., 2002. Life cycle impact assessment of pesticides on human health and ecosystems. Agriculture, Ecosystems and Environment 93, 379-392.

Peterson, R.K.D., Hulting, A.G., 2004. A comparative ecological risk assessment for herbicides used on spring wheat: the effect of glyphosate when used within a glyphosate-tolerant wheat system. Weed Science 52, 834-844.

Reichenberger, S., Bach, M., Skitschak, A., Frede, H.-G., 2007. Mitigation strategies to reduce pesticide inputs into ground- and surface water and their effectiveness; A review. Science of the Total Environment 384, 1-35.

RIVM, VROM, VWS, 1998. Uniform System for the Evaluation of Substances 2.0 (USES 2.0). RIVM report no. 679102044. National Institute of Public Health and the Environment (RIVM), Ministry of Housing, Spatial Planning and the Environment (VROM), Ministry of Health, Welfare and Sport (VWS), The Netherlands.

Roberts, T., 1998. Metabolic Pathways of Agrochemicals. Part 1: Herbicides and Plant Growth Regulators. The Royal Society of Chemistry, Cambridge, UK.

Rosenbaum, R.K., Bachmann, T.M., Swirsky Gold, L., Huijbregts, M.A.J., Jolliet, O., Juraske, R., Koehler, A., Larsen, H.F., MacLeod, M., Margni, M., MacKone, T.E. Payet, J., Schuhmacher, M., van de Meent, D., Hauschild, M.Z., 2008. USE-tox-the UNEP-SETAC toxicity model: recommended characterisation factors for human toxicity and freshwater ecotoxicity in life cycle impact assessment. International Journal of Life Cycle Assessment 13, 532-546.

Rouchaud, J., Neus, O., Callens, D., Bulcke, R., 1998. Sulcotrione soil persistence and mobility in summer maize and winter wheat crops. Weed Research 38, $361-371$.

Rouchaud, J., Metsue, M., van Himme, M., Bulcke, R., Gillet, J., Vanparys, L., 1992. Soil degradation of metazachlor in agronomic and vegetable crop fields. Weed Science 40, 149-154.

Shaner, D.L., 2000. The impact of glyphosate-tolerant crops on the use of other herbicides and on resistance management. Pest Management Science 56, 320-326

Sinclair, C.J., Boxall, A.B.A., 2003. Assessing the ecotoxicity of pesticide transformation products. Environmental Science and Technology 37, 4617-4625.

Sørensen, S.R., Bending, G.D., Jacobsen, C.S., Walker, A., Aamand, J., 2003. Microbial degradation of isoproturon and related phenylurea herbicides in and below agricultural fields. FEMS Microbiology Ecology 45, 1-11.

Traas, T.P., Smit, C.E., 2003. Environmental risk limits for aminomethylphosphonic acid (AMPA). RIVM report no. 601501018/2003. National Institute of Public Health and the Environment (RIVM), The Netherlands.

Turner, R., 2004. The field-scale evaluation of herbicide-tolerant genetically modified crops conducted in the UK (1998-2003). Journal of Commercial Biotechnology $10,224-233$.

USEPA (U.S. Environmental Protection Agency and Science Applications International Corporation), 2006. Life cycle assessment: principles and practices. EPA/ 600/R-06/060, May 2006. http://www.epa.gov/nrmrl/lcaccess/lca101.html (accessed 11.06.10).

Van Zelm, R., Huijbregts, M.A.J., van de Meent, D., 2010. Transformation products in the life cycle impact assessment of chemicals. Environmental Science and Technology 44, 1004-1009.

Van Zelm, R., Huijbregts, M.A.J., Posthuma, L., Wintersen, A., van de Meent, D., 2009. Pesticide ecotoxicological effect factors and their uncertainties for freshwater ecosystems. International Journal of Life Cycle Assessment 14, 43-51.

Veiga, F., Zapata, J.M., Fernandez Marcos, M.L., Alvarez, E., 2001. Dynamics of glyphosate and aminomethylphosphonic acid in a forest soil in Galicia, northwest Spain. Science of the Total Environment 271, 135-144.

Vereecken, H., 2005. Mobility and leaching of glyphosate: a review. Pest Management Science 61, 1139-1151.

Vischetti, C., Marucchini, C., Leita, L., Ceccon, P., Giovanardi, R., 1997. Soil behaviour of metamitron in laboratory and lysimeter studies. Agronomie 17, 367-373.

Wauchope, R.D., Estes, T.L., Allen, R., Baker, J.L., Hornsby, A.G., Jones, R.L., Richards, R.P. Gustafson, D.I., 2002. Predicted impact of transgenic, herbicide-tolerant corn on drinking water quality in vulnerable watersheds of the mid-western USA. Pest Management Science 58, 146-160.

WHO (World Health Organization), 2005. Glyphosate and AMPA in Drinking-Water. Background Document for Development of WHO Guidelines for DrinkingWater Quality. World Health Organization (WHO/SDE/SWH/03.04/97). 